natural participant in this work, but there would have to be an extension of its terms of reference to allow the conservancy to operate outside the United Kingdom. An official of the Royal Society offers the Charles Darwin Foundation Research Station on the Galapagos Islands as a model for what might be done on Aldabra. It seems to be understood that the Smithsonian Institution, urged on by the National Academy of Sciences in the United States, will be a willing partner in this part of the operation. Two of the nine members of the Royal Society's expedition to Aldabra this summer were from the Smithsonian Institution.

The international research station is a long-term objective, however. The expedition now returned from Aldabra was also impressed with the need for more urgent steps to be taken. One problem is to prevent the fishing of the waters around the island. At present the arrangement is that a Seychellian has been licensed to fish off Aldabra, with the result that there is a danger of the green turtles becoming extinct. Dr D. R. Stoddart of the University of Cambridge, who has just returned from the island, says that the way in which the fishermen live on the island temporarily may be almost as great a danger. In the year ahead, the Royal Society plans to send another expedition to Aldabra in January, and one member of the party of twenty-Mr M. J. Penny, an ornithologist-will probably stay there until March 1969. Everybody hopes that plans for the permanent conservation of the island will by then be complete.

\title{
Moles Underground
}

\section{Sorry, for copyright reasons some images on this page may not be available online}

\footnotetext{
This picture, the first ever taken of moles underground, won the Wildlife Carneraman of 1967 competition organized by the Council for Nature and Wildlife and the Countryside magazine. The picture, taken by Mr Peter Stafford, shows a parent mole entering its nesting chamber three feet beneath a field in Sussex. 'The young are lying in a nest of dead grass, with at least two tunnels leaving the chamber. The feeding habits and activity of moles were described by Kenneth Mellanby in Nature (215, 1128; $1967)$.
}

\section{Parliament in Britain}

\section{Foot and Mouth Disease}

Mr P. Gordon WaLker stated that research on foot and mouth disease was concentrated at the Animal Virus Research Institute, Pirbright, where it made up about three-quarters of the work of the institute. Grants from the Agricultural Research Council to the institute during the last five financial years had been as

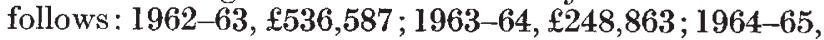
$£ 390,462 ; 1965-66, £ 499,379 ; 1966-67, £ 522,521$. Net expenditure, and hence the size of grant needed, varied with the revenue from the sale of vaccines overseas, which in turn depended on outbreaks of the disease overseas. (Written answer, November 20.)

\section{Dounreay}

Two employees have left the Dounreay Experimental Reactor Establishment to go to the United States during the last six months. Mr A. Wedgwood Benn, giving the figures, stated that one was a senior machine operator accompanying her American husband on his return home. The other was a scientific officer who mentioned better pay as his main reason for leaving. (Written answer, November 21.)

Seals

THE Minister of Agriculture, Fisheries and Food, Mr F. Peart, announced that as the National Trust was unable, on the basis of its existing information, to agree to continue culling seals on the Farne Islands, the Natural Environment Research Council suggested that it would be desirable to have a review of the scientific facts and their interpretation by a wide range of scientific opinion. The council was arranging a meeting of scientists as soon as possible. (Oral answer, November 21.)

Defence

Mr Denis Healey came in for some vigorous criticism when he announced full details of the defence cuts which the British Government has made as part of the devaluation package. The word betrayal was mentioned by at least one member, but others thought Mr Healey had not done enough. What he has done is bring forward the date for the withdrawal of the aircraft carrier Victorious, saving $f 4$ million, cancelled 8 Buccaneer aircraft, saving $£ 6$ million, deferred some Army equipment and cancelled an order for helicopters from the United States, saving another $£ 11$ million. There will also be a further reduction of $f 8$ million in research and development expenditure, on top of the $£ 30$ million cut $\mathrm{Mr}$ Healey made in the last financial crisis. Nuclear weapon development will be cut by $£ 2$ million, and other savings will be made by not replacing wastage of civilians in defence establishments. The Government had also decided not to build the staging post on Aldabra, although $\mathrm{Mr}$ Healey admitted that a decision had been made to go ahead, subject to approval from the American government. Aldabra would have been a valuable addition to British strategic flexibility, he said, but the Services must now forgo it. "I dare say that other sections of the community may see some benefits in this decision." The cancellation would save only $\mathfrak{4} 4$ million this year, he said; the bulk of the reductions comes in the form of minor cuts and deferments. More than f60 million, he said, would be saved in this way. (Debate, November 27.) 